\title{
Hubungan panjang bobot dan faktor kondisi ikan petek, Leiognathus equulus (Forsskål, 1775) di Teluk Pabean, Jawa Barat
}

[Length-weight relationship and condition factor of common ponyfish, Leiognathus equulus (Forsskål, 1775) in Pabean Bay, Indramayu, West Java]

\author{
Reiza Maulana Aditriawan ${ }^{1 区}$, Nico Runtuboy $^{2}$ \\ ${ }^{1}$ Masyarakat Iktiologi Indonesia \\ ${ }^{2}$ Balai Besar Pengembangan Budidaya Laut Lampung
}

Diterima: 9 Agustus 2017; Disetujui: 17 Oktober 2017

\begin{abstract}
Abstrak
Penelitian ini bertujuan untuk menentukan hubungan panjang bobot dan faktor kondisi ikan petek yang ada di Teluk Pabean, Indramayu. Penelitian dilaksanakan selama satu tahun dari bulan April 2016 hingga bulan Maret 2017. Ikan contoh ditangkap dengan menggunakan alat tangkap yaitu jaring insang dan sero. Jumlah ikan yang tertangkap sebanyak 154 ekor dengan kisaran panjang total $18-141 \mathrm{~mm}$ dan bobot $0,05-41,35 \mathrm{~g}$. Hubungan panjang-bobot ikan petek sepanjang tahun 2016 adalah $\mathrm{W}=7 \times 10^{-06} \mathrm{~L}^{3,1983}$. Hasil ini menunjukkan bahwa pola pertumbuhan ikan bersifat alometrik positif. Faktor kondisi ikan petek berfluktuasi berkisar antara 0,67-1,42.
\end{abstract}

Kata penting: alometrik positif, bobot, faktor kondisi, panjang

\begin{abstract}
This study is aimed to determine length-weight relationship and condition factor of common ponyfish in Pabean Bay, Indramayu. The study was carried out for one year, from April 2016 to March 2017. Fish collection were caught using gillnet and set net. total of 154 individual fishes were caught, the fish samples ranged from $18-141 \mathrm{~mm}$ in length and $0.05-41.35 \mathrm{~g}$ in weight. The length-weight relationship of ponyfish throughout a year was $\mathrm{W}=7 \times 10^{-06} \mathrm{~L}^{3,1983}$. The result indicated that the growth pattern of fish was positive allometric. The relative condition factor of ponyfish was varied from $0,67-1,42$
\end{abstract}

Keywords: condition factor, length, positive allometric, weight

\section{Pendahuluan}

Ikan petek (Leiognathus equulus, Forsskål 1775) tinggal di dasar perairan hingga mencapai permukaan (bentopelagik), sebagian besar hidup di laut, beberapa di air payau dan air tawar pada kedalaman 10-110 m, dan sampai kedalaman 40$60 \mathrm{~m}$ biasanya ditemukan dalam gerombolan besar (James 1984). Saat terjadi pasang ikan petek masuk ke dalam daerah estuari sehingga ditemukan pula di sekitar muara sungai, pesisir pantai yang berlumpur, dan mangrove. Menurut IUCN (2012), spesies yang tergabung dalam Famili Leiognathidae masuk ke dalam kategori beresiko rendah (least concern) yang artinya spesies ini

$\square$ Penulis korespondensi

Alamat surel:reizascs@gmail.com tidak masuk ke dalam kategori punah maupun terancam punah. Selain memiliki wilayah persebaran yang luas, ikan petek juga memiliki jumlah yang melimpah. Pemanfaatan ikan petek telah dilakukan sejak lama di beberapa daerah seperti di perairan Barat Sumatra. Hasil penelitian Wedjadmiko (2007) yang membandingkan komposisi hasil tangkapan pukat harimau tahun 2005 dan 2006 menunjukkan famili Leiognathidae merupakan famili paling dominan tertangkap. Di daerah lain seperti Mayangan - Subang, ikan petek merupakan ikan hasil tangkap sampingan yang dominan sehingga banyak di pasarkan dalam bentuk kering (Novitriana et al. 2004). Di Teluk Pabean, Indramayu ikan petek merupakan jenis ikan hasil tangkap sampingan yang penting kare- 
na merupakan bahan campuran utama untuk pembuatan terasi.

Penelitian mengenai berbagai macam aspek mengenai ikan petek telah dilakukan seperti potensi penangkapan (Wedjadmiko 2007), reproduksi (Novitriana et al. 2004), dan kebiasaan makan (Prihatiningsih et al. 2014). Penelitian aspek pertumbuhan diperlukan karena sebelumnya belum ada informasi penelitian mengenai ikan petek di Teluk Pabean. Penelitian bertujuan menganalisis hubungan panjang bobot dan menganalisis faktor kondisi ikan petek di Teluk Pabean.

\section{Bahan dan metode}

Penelitian dilakukan di perairan Teluk Pabean, Kabupaten Indramayu, Provinsi Jawa
Barat. Pengambilan ikan contoh dilakukan dalam interval waktu satu kali dalam satu bulan selama satu tahun antara bulan April 2016 hingga bulan Maret 2017. Pengambilan ikan contoh dilakukan di tiga stasiun. Stasiun 1 berlokasi di dalam area Teluk Pabean yang merupakan lokasi aktivitas penangkapan menggunakan alat tangkap sero. Stasiun 2 berlokasi di mulut sungai Cimanuk yang merupakan daerah berbatasan langsung dengan laut dan banyak ditumbuhi oleh mangrove. Stasiun 3 berlokasi di sebelah timur muara yang merupakan daerah aktivitas penangkapan menggunakan jaring. Lokasi pengambilan contoh ikan dapat dilihat dalam Gambar 1.

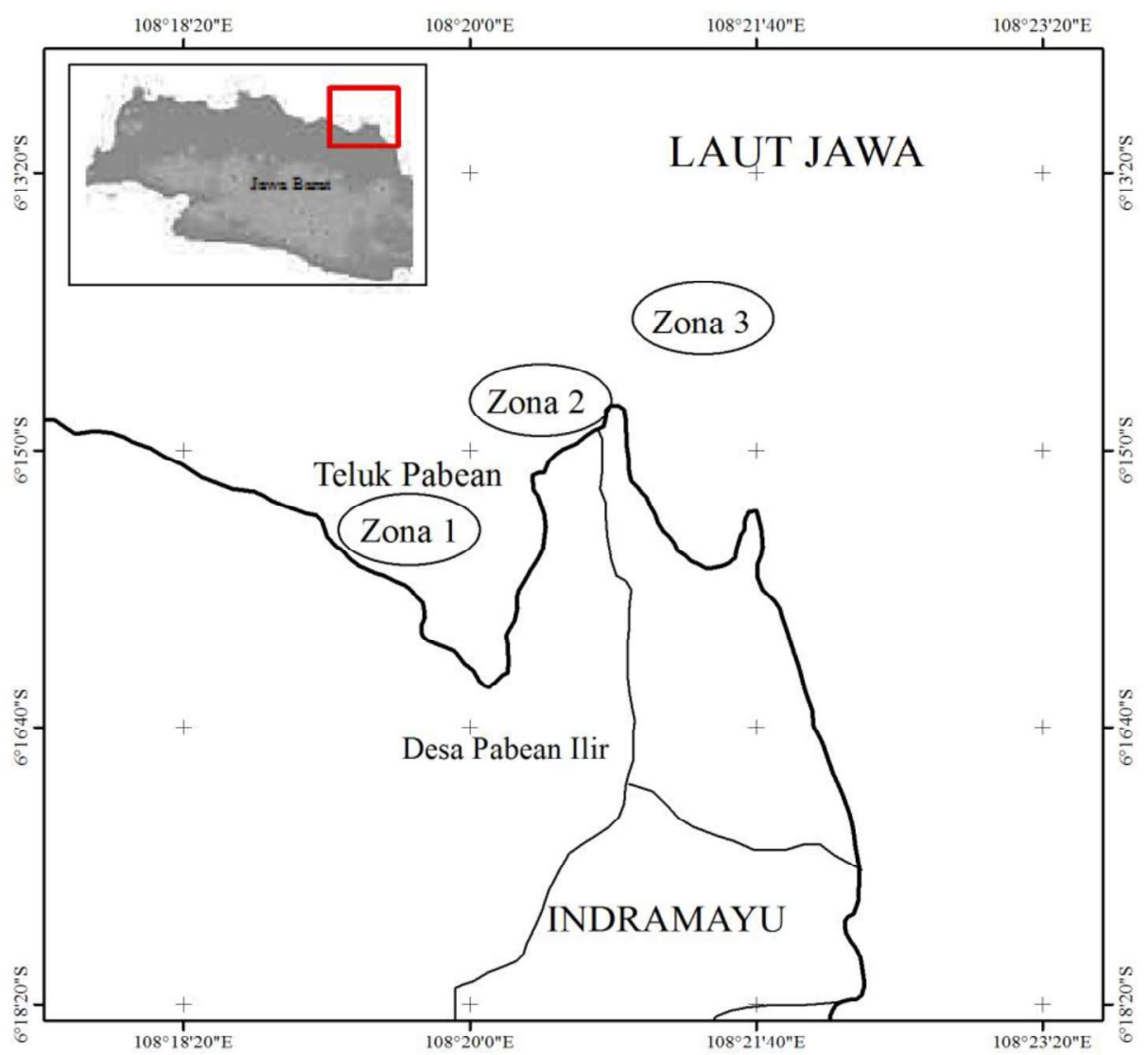

Gambar 1. Peta lokasi pengambilan contoh ikan di Teluk Pabean, Indramayu. 
Ikan contoh ditangkap menggunakan dua alat tangkap yaitu sero dan jaring insang. Jaring insang yang digunakan memiliki dimensi panjang 400 meter, tinggi 1,5 meter dan ukuran mata jaring 1,5 inci. Jaring dipasang selama 60 menit lalu diangkat sebelum kembali ditebar pada setiap titik sampling. Alat tangkap sero terdiri atas susunan pagar-pagar semi permanen yang akan menuntun ikan masuk kedalam perangkap berbentuk kotak persegi berukuran $2 \mathrm{~m}$ x $2 \mathrm{~m}$. Perangkap sero dioperasikan pada pagi hari pukul 06.00 selama 24 jam.

Ikan contoh yang didapat diawetkan dengan formalin $10 \%$ dan dikelompokkan menurut area penangkapannya untuk kemudian dibawa ke Laboratorium. Analisis berupa pengukuran panjang total dari ujung kepala hingga pangkal ekor dan ditimbang bobot tubuhnya dengan timbangan digital. Data ini digunakan untuk menentukan hubungan panjang-bobot dan faktor kondisi ikan. Analisis hubungan panjang-bobot bertujuan untuk menentukan pola pertumbuhan ikan di alam dan dihitung dengan menggunakan persamaan berikut:

$$
\mathrm{W}=\mathrm{aL}^{\mathrm{b}}
$$

Keterangan: $\mathrm{W}=$ bobot ikan $(\mathrm{g}), \mathrm{L}=$ panjang total ikan $(\mathrm{mm})$, a dan b adalah konstanta hasil regresi.

Uji t $(p<0,05)$ digunakan untuk menguji apakah nilai $b=3$ atau tidak. Jika $b=3$ berarti ikan mempunyai pola pertumbuhan isometrik dan sebaliknya bila $b \neq 3$ berarti pola pertumbuhan ikan bersifat alometrik (Effendie 2002).

Faktor kondisi merupakan sebuah nilai indeks yang menunjukkan kondisi kesehatan ikan. Nilai indeks tersebut diperoleh dengan rumus Le Cren (1951):

$$
\mathrm{K}=\frac{W}{a L b}
$$

Keterangan: $\mathrm{K}=$ faktor kondisi, $\mathrm{W}=$ bobot ikan $(\mathrm{g}), \mathrm{L}=$ panjang total ikan (mm), a dan b adalah konstanta.

\section{Hasil}

Total ikan petek yang diperoleh selama penelitian sebanyak 154 ekor dengan beragam ukuran. Panjang total ikan petek berkisar antara 18 - $141 \mathrm{~mm}$, sedangkan kisaran bobot antara 0,05 - 41,35 gram. Pengelompokan kelas panjang ikan petek diperoleh 8 kelompok kelas panjang dengan frekuensi tertinggi yaitu 73 ekor pada selang kelas 60-73 mm (Gambar 2).

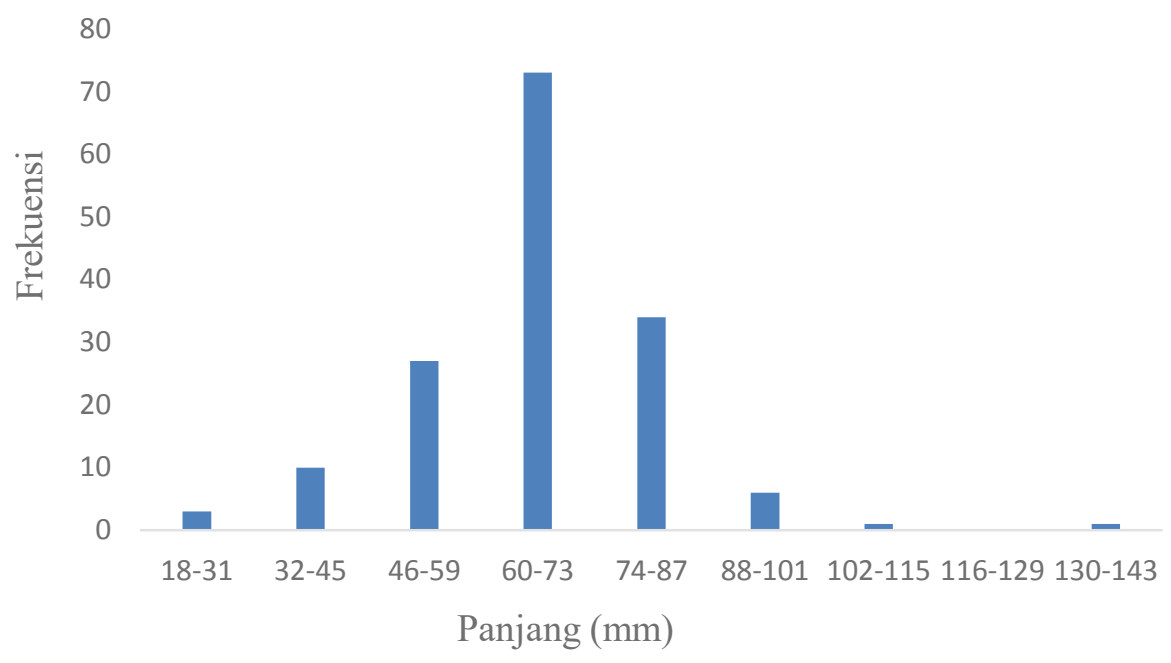

Gambar 2. Sebaran frekuensi panjang ikan petek (Leiognathus equulus) 
Hasil tangkapan ikan petek setiap bulan pengamatan cukup bervariasi dan juga berfluktuasi (Gambar 3). Jumlah ikan petek yang tertangkap tertinggi pada bulan Juni 2016, yakni sebanyak 35 ekor, lalu mengalami penurunan sebelum kembali mengalami puncak tangkapan pada bulan November 2016 yakni sebanyak 20 ekor, pola yang sama terjadi pada selang tiga bulan pengamatan, yaitu pada bulan Februari sebanyak 28 ekor yang selama dua bulan sebelumnya hasil tangkapan mengalami penurunan.

Hubungan panjang-bobot dianalisis dengan menggunakan data panjang total dan bobot total ikan contoh. Hubungan panjangbobot ikan petek selama penelitian ini dijelaskan pada Gambar 4 .

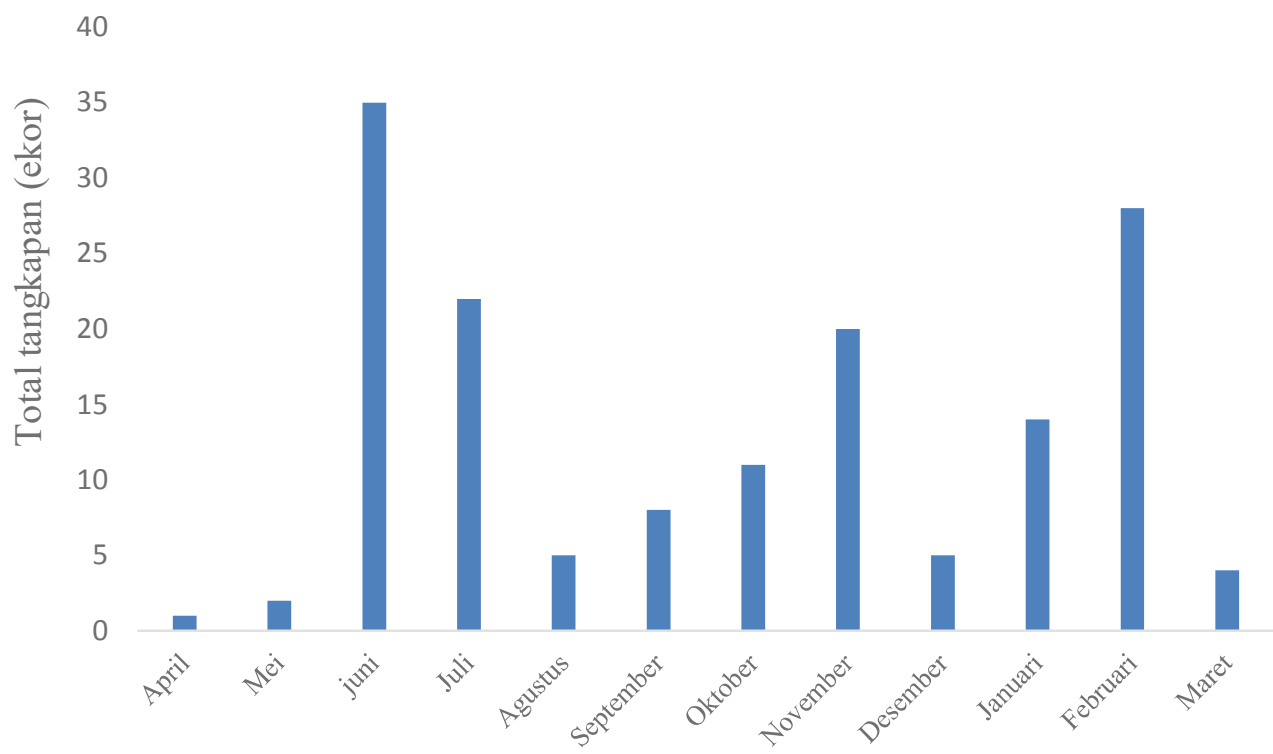

Gambar 3. Grafik total tangkapan setiap bulan

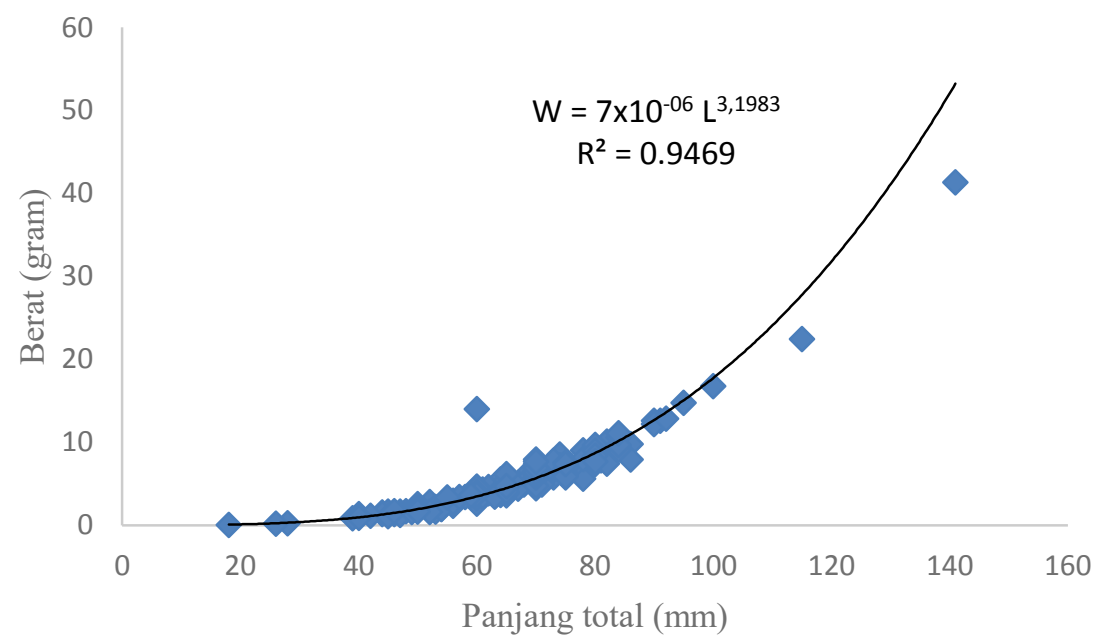

Gambar 4. Hubungan panjang bobot ikan petek 
Tabel 1. Faktor kondisi ikan petek per bulan

\begin{tabular}{lccccc}
\hline Bulan & $\begin{array}{c}\text { Jumlah ikan } \\
(\text { ekor })\end{array}$ & $\begin{array}{c}\text { Panjang } \\
(\mathrm{mm})\end{array}$ & $\begin{array}{c}\text { Bobot } \\
(\text { gram })\end{array}$ & $\begin{array}{c}\text { Kisaran faktor } \\
\text { kondisi }\end{array}$ & $\begin{array}{c}\text { Faktor kondisi } \\
\text { rata-rata }\end{array}$ \\
\hline April & 1 & 115 & 22,44 & 0,81 & 0,81 \\
Mei & 2 & $70-70$ & $7,37-7,91$ & $1,29-1,39$ & 1,34 \\
Juni & 34 & $44-95$ & $1,52-14,73$ & $0,69-1,26$ & 0,97 \\
Juli & 22 & $40-100$ & $1,10-16,76$ & $0,78-1,26$ & 1,00 \\
Agustus & 5 & $62-82$ & $4,04-7,99$ & $0,78-1,09$ & 0,95 \\
September & 8 & $70-80$ & $4,87-9,69$ & $0,85-1,19$ & 0,99 \\
Oktober & 11 & $50-84$ & $0,86-12,86$ & $0,74-1,30$ & 0,97 \\
November & 20 & $39-92$ & $0,86-12,86$ & $0,87-1,42$ & 1,03 \\
Desember & 5 & $61-71$ & $3,49-6,03$ & $0,83-1,19$ & 0,97 \\
Januari & 14 & $60-70$ & $3,90-6,83$ & $0,84-1,33$ & 1,10 \\
Februari & 28 & $40-141$ & $0,88-41,35$ & $0,69-1,38$ & 1,00 \\
Maret & 4 & $18-59$ & $0,05-3,58$ & $0,67-1,09$ & 0,82 \\
\hline
\end{tabular}

Analisis hubungan panjang bobot ikan petek diperoleh persamaan $\mathrm{W}=7 \times 10^{-06} \mathrm{~L}^{3,1983}$ dengan nilai $\mathrm{R}^{2}$ sebesar 0,9469 , nilai koefesien korelasi (r) yang didapat mendekati 1 yaitu sebesar 0,9731. Analisis uji t membuktikan bahwa pola pertumbuhan ikan petek adalah alometrik positif, artinya pertambahan bobot lebih besar dibandingkan pertambahan panjang.

Hasil analisis perhitungan nilai faktor kondisi ikan petek ditampilkan pada Tabel 1. Faktor kondisi individu ikan tiap bulan terendah terjadi pada bulan Maret 2017 (sebesar 0,67) dan tertinggi pada bulan November 2016 (sebesar 1,42). Nilai faktor kondisi rata-rata per bulan terendah ditemukan selama penelitian memperlihatkan bahwa pada bulan April 2016 merupakan nilai terendah, sedangkan nilai faktor kondisi rata-rata perbulan tertinggi yaitu pada bulan Mei 2016.

\section{Pembahasan}

Hasil penelitian mendapatkan data panjang dan bobot ikan petek yang bervariasi, kisaran panjang dan bobot ikan petek tidak jauh berbeda yang berkisar antara $18 \mathrm{~mm}$ hingga $141 \mathrm{~mm}$ dan bobot $0,05 \mathrm{~g}$ hingga $41,35 \mathrm{~g}$. Uji t terhadap persamaan hubungan panjang bobot menunjuk- kan pola pertumbuhan yang sama yaitu alometrik yang juga berarti pertambahan bobot tidak sebanding dengan pertambahan panjang, dilihat dari nilai b yang diperoleh yaitu sebesar 3,1983 mengungkapkan pertambahan bobot lebih besar dibandingkan pertambahan panjang. karena nilai b lebih besar dari 3 (alometrik positif).

Jenning et al. (2001) menyatakan beberapa faktor memengaruhi pola pertumbuhan, diantaranya kondisi fisiologis dan lingkungan seperti suhu, $\mathrm{pH}$, dan salinitas, serta kondisi geografis. Perkembangan gonad dan ketersediaan makanan di habitat juga dapat memengaruhi pola pertumbuhan menurut Froese (2006).

Faktor kondisi adalah indeks yang memperlihatkan kondisi kesehatan ikan secara kuantitatif. Penentuan nilai faktor kondisi didasarkan pada pola pertumbuhan. Pola pertumbuhan ikan petek di semua stasiun selama penelitian menunjukkan pertumbuhan alometrik. Analisis faktor kondisi ikan petek di Teluk Pabean, Indramayu memiliki nilai yang berfluktuas tiap bulan. Nilai faktor kondisi terendah pada bulan Maret 2017 $(0,6788)$ pada kisaran panjang ikan petek $18-59$ $\mathrm{mm}$ dan nilai faktor tertinggi pada bulan Juni $2016(4,0418)$ pada kisaran panjang ikan petek 
$44-95 \mathrm{~mm}$. Nilai faktor kondisi rata-rata per bulan memperlihatkan bulan April 2016 merupakan nilai terendah yaitu sebesar 0,8087 , sedangkan nilai faktor kondisi rata-rata per bulan tertinggi yaitu pada bulan Mei 2016.

Nilai faktor kondisi dapat berfluktuasi sebagai representasi dari banyaknya faktor yang mempengaruhi, seperti dikatakan oleh Sarkar et al. (2013) bahwa nilai faktor kondisi berbeda disebabkan oleh adanya perbedaan musim yang berlangsung sepanjang tahun. Musim pemijahan menaruh andil yang menyebabkan faktor kondisi rendah karena pada periode ini energi lebih banyak di butuhkan bagi perkembangan gonad (de Souza et al. 2008). Selain itu diduga pada saat ikan betina matang gonad tidak melakukan aktivitas makan sehingga asupan energi yang dibutuhkan berasal dari cadangan lemak dalam tubuh serta ketersediaan makanan di alam tidak melimpah sehingga perkembangan gonad menjadi lambat dan ukuran gonad menjadi kecil, kondisi ini telah ditemukan pada ikan L. equulus di perairan pantai Mayangan (Novitriana et al. 2004).

\section{Simpulan}

Pola pertumbuhan ikan petek memperlihatkan pertambahan bobot lebih besar dibandingkan pertambahan panjang (alometrik positif). Faktor kondisi ikan petek berfluktuasi tiap bulan.

\section{Persantunan}

Penulis mengucapkan terima kasih kepada Pak Suwara dan keluarga, Pak Kirwan dan nelayan lainnya di Teluk Pabean yang telah membantu selama kegiatan penelitian di lapangan.

\section{Daftar pustaka}

de Souza EJ, Fragoso-Moura EN, Fenerich-Verani N, Rocha O, Verani JR. 2008. Popu- lation structure and reproductive biology of Cichla kelberi (Perciformes, Cichlidae) in Lobo Reservoir, Brazil. Neotropical Ichthyology, 6(2): 201-210.

Effendie MI. 2002. Biologi Perikanan. Yayasan Pustaka Nusatama. Yogyakarta. $163 \mathrm{hlm}$.

Froese R. 2006. Cube law, condition factor and weight-length relationships: history, metaanalysis and recommendations. Journal of Applied Ichtyology, 22(4):241-253.

IUCN. 2012. The IUCN Red List of Threatened Species. UK. ISSN 2307-8235. Diunduh 17 Juli 2017

James PSBR. 1984. Leiognathidae. In: Fischer W, Bianchi G (eds.). FAO species identification sheets for fishery purposes. Western Indian Ocean (Fishing area 51). Vol. 2. FAO. Rome.

Jennings S, Kaiser MJ, Reynolds JD. 2001. Marine Fisheries Ecology. Blackwell Sciences. Oxford. 417 p.

Le Cren ED. 1951. The length-weight relationship and seasonal cycle in gonad weight and condition in the perch (Perca fluviatilis). Jurnal of Animal Ecology, 20(2): 201-219.

Novitriana R, Ernawati Y, Rahardjo MF. 2004. Aspek pemijahan ikan petek, Leiognathus equulus, Forsskål 1775 (Fam. Leiognathidae) di Pesisir Mayangan Subang, Jawa Barat. Jurnal Iktiologi Indonesia, 4(1): 713.

Prihatiningsih, Pustika Ratnawati, Muhamad Taufik. 2014. Biologi reproduksi dan kebiasaan makan ikan petek (Leiognathus spledens) di Perairan Banten dan sekitarnya. Bawal, 7(1): 1-8

Sarkar UK, Khan GE, Dabas A, Pathak AK, Mir JI, Rebello SC, Pal A, Singh SP. 2013. Length weight relationship and condition factor of selected freshwater fish species found in River Ganga, Gomti and Rapti, India. Journal of Environmental Biology, 34(5): 1951-1956.

Wedjadmiko. 2007. Komposisi ikan petek (Leiognathidae) di Perairan Barat Sumatra. Jurnal Iktiologi Indonesia, 7(1): 9-14. 